\title{
DETERMINAN YANG BERHUBUNGAN DENGAN PEMBERIAN MP-ASI DINI PADA BAYI USIA 0-6 BULAN
}

\author{
Rafika Oktova \\ Program Studi D-III Kebidanan STIKes Payung Negeri Pekanbaru \\ Email: rafikamkeb@gmail.com
}

\begin{abstract}
Related Determinan to Premature Complementary Feeding. SDKI (2012) said the distribution of MP-ASI early age in Indonesia: 0-1 months of 49,3\%, at the age 2-3 month of 51\%, and age $4-5$ months of $73 \%$. If complementary feeding given at the age of under six months, digestive system of infants have not having enzymes to digest food, digestion and kidney worked havier, can lead cough, diarrhea, colic, and allergic. The lowest percentage of the scope breastfeeding exclusive was at Puskesmas Rumbai Pesisir, about $37,27 \%$. This study was to know factors that deals with the provision of premature complementary feeding on children aged 6-0 months in the work area of Puskesmas Rumbai Pesisir Pekanbaru. This study was analytic design cross sectional. Population were all the mother who have a baby aged 6-0 months, total population were 1135 people, and 92 as total sample. Data were analyzed by test chi-square $(\alpha<0,05)$. Results were obtained the majority of respondents knowledgeable good 67 people $(72,8 \%)$, educated low as many as 68 people $(73,9 \%)$, does not work as many as 69 people $(75 \%)$ and family income high 53 people $(57,6 \%)$. Statistical tests chi-square revealed that there were relation between knowledge and education with the premature complementary feeding. And there was no related between work and family income with give premature complementary feeding. Expected health workers can cooperate with healthcare and community figures in providing information or tutoring directed regarding the provision of complementary feeding time.
\end{abstract}

Keywords: Knowledge, Education, Work, Family income, Premature complementary feeding

\begin{abstract}
Abstrak: Determinan yang Berhubungan dengan Pemberian MP-ASI Dini Pada Bayi Usia 06 Bulan. Menurut SDKI (2012) di Indonesia pemberian MP-ASI dini : usia 0-1 bulan sebesar $49,3 \%$, pada usia $2-3$ bulan $51 \%$, dan usia $4-5$ bulan sebesar $73 \%$. Bila MP-ASI diberikan saat usia dibawah 6 bulan, sistem pencernaan bayi belum memiliki enzim untuk mencerna makanan sehingga memberatkan kerja pencernaan dan ginjal, dapat menimbulkan reaksi batuk, diare, kolik, dan alergi. Persentase cakupan pemberian ASI eksklusif terendah adalah di Puskesmas Rumbai Pesisir yaitu sebanyak 37,27\%.Tujuan penelitian untuk mengetahui faktor-faktor yang berhubungan dengan pemberian MP-ASI dini pada bayi usia 0-6 bulan di Wilayah Kerja Puskesmas Rumbai Pesisir Pekanbaru. Penelitian ini adalah analitik desain cross sectional. Populasi penelitian adalah seluruh ibu yang mempunyai bayi 0-6 bulan berjumlah 1135 orang.Sampel berjumlah 92 orang. Analisis datadengan uji chi-square $(\alpha<0,05)$.Hasil uji statistik chi-square menunjukkan bahwa terdapat hubungan antara pengetahuan dan pendidikan dengan pemberian MP-ASI dini dan tidak terdapat hubungan antara pekerjaan dan pendapatan keluarga dengan pemberian MP-ASI dini.Diharapkan tenaga kesehatan dapat bekerjasama dengan kader kesehatan dan tokoh masyarakat dalam memberikan penyuluhan atau bimbingan terarah tentang pemberian MP-ASI yang tepat waktu.
\end{abstract}

Kata kunci: Pengetahuan, Pendidikan, Pekerjaan, Pendapatan keluarga, MP-ASI dini

Air Susu Ibu (ASI) eksklusif berdasarkan Peraturan Pemerintah Nomor 33 tahun 2012 adalah ASI yang diberikan kepada bayi sejak dilahirkan selama 6 bulan, tanpa menambahkan dan atau mengganti dengan makanan atau minuman lain kecuali obat, vitamin dan mineral (Kemenkes RI, 2016). Menurut Depkes (2006), salah satu pencapaian tumbuh kembang optimal pada bayi adalah memberikan Makanan Pendamping Air Susu Ibu (MP-ASI) sejak bayi berusia 6-24 bulan dan meneruskan pemberian ASI sampai anak berusia 24 bulan atau lebih.

Di Indonesia hampir 9 dari $10 \mathrm{ibu}$ pernah memberikan ASI, namun penelitian IDAI menemukan hanya $49,8 \%$ yang memberikan ASI secara eksklusif selama 6 bulan. Rendahnya cakupan pemberian ASI secara eksklusif ini dapat berdampak pada kualitas hidup generasi penerus bangsa dan juga pada perekonomian nasional (Fadhila \& Ninditya, 2016). 
Menurut Kemenkes RI (2013), di Indonesia bayi yang mendapatkan ASI eksklusif sebesar $30,2 \%$ dan tidak mendapatkan ASI eksklusif sebesar $69,8 \%$. MenurutDinkesProvinsi Riau (2014) bayi yang mendapatkan ASI eksklusif sebesar $52,4 \%$ dan bayi yang tidak mendapatkan ASI eksklusif sebesar 48,6\%, meskipun pemberian ASI eksklusif dari tahun 2011 sebesar 45,9\% sampai tahun 2014 sebesar $52,4 \%$ terus meningkat, tetapi belum mencapai target 90\%. Cakupan ASI eksklusif yang tertinggi di Provinsi Riau tahun 2014 adalah Indragiri Hilir sebesar 69,8\%, dan cakupan ASI eksklusif yang terendah terdapat di Kepulauan Meranti sebesar 39,8\%.

Pemberian MP-ASI dini pada bayi usia dibawah 6 bulan di Indonesia menurut M. DHS. (2013) bayi yang mendapat MP-ASI dini usia 0-1 bulan sebesar $49,3 \%$, pada usia $2-3$ bulan $51 \%$, dan usia 4-5 bulan sebesar 73\%. Menurut Kemenkes RI (2013) jenis makanan prelakteal yang paling banyak diberikan kepada bayi baru lahir yaitu susu formula sebesar $(79,8 \%)$, madu $(14,3 \%)$, dan air putih $(13,2 \%)$.

Bila MP-ASI diberikan saat usia dibawah 6 bulan, sistem pencernaannya belum memiliki enzim untuk mencerna makanan sehingga memberatkan kerja pencernaan dan ginjal bayi. Selain itu, usus bayi belum dapat menyaring protein dalam jumlah besar, sehingga dapat menimbulkan reaksi batuk, diare, kolik, dan alergi (Arif.N, 2009). Pada bulan-bulan pertama, saat bayi berada pada kondisi yang sangat rentan, pemberian makanan atau minuman lain selain ASI akan meningkatkan resiko terjadinya diare, infeksi telinga, alergi, meningitis, leukimia, Sudden Infant Death Syndrome/ SIDS-sindrom kematian tiba-tiba pada bayi, penyakit infeksi dan penyakit-penyakit lain yang biasa terjadi pada bayi (Imelda, 2010).

MP-ASI dapat diberikan saat usia bayi mencapai 6 bulan. Ukuran kecukupan produksi ASI bagi bayi dapat dilihat dari kenaikan berat badan dan kesehatan bayi (Arif N, 2009). Menurut Kristanto \& Yusiana (2012) banyak faktor yang berhubungan dengan pemberian MPASI dini oleh ibu, faktor-faktor tersebut meliputi pengetahuan, kesehatan dan pekerjaan ibu, iklan MP-ASI, petugas kesehatan, budaya dan sosial ekonomi.

Berdasarkan survei awal, data yang didapat dari Dinas Kesehatan Kota Pekanbaru tahun 2015 diperoleh cakupan ASI eksklusif sebesar 55,22\%. Persentase cakupan pemberian ASI eksklusif terendah adalah di Puskesmas Rumbai Pesisir yaitu sebanyak $37,27 \%$ dari 20 puskesmas yang ada di Kota Pekanbaru.
Tujuan penelitian untuk menganalisis faktor-faktor yang berhubungan dengan pemberian MP-ASI dini pada bayi usia 0-6 bulan.

\section{METODE PENELITIAN}

Jenis penelitian adalah analitikdengan desain cross sectional corelative.Penelitian dilakukan pada bulan Januari-Februari 2017 di Wilayah Kerja Puskesmas Rumbai Pesisir Pekanbaru. Populasi dalam penelitian ini adalah seluruh ibu yang mempunyai bayi usia 0-6 bulan di Wilayah Kerja Puskesmas Rumbai Pesisir Pekanbaru periode Januari-Desember 2015 berjumlah 1135 orang. Sampel penelitian 92 orang yang diambil secara purposive sampling. Variabel Independen dalam penelitian ini adalah determinan: pengetahuan, pendidikan, pekerjaan dan pendapatan keluarga. Variabel dependen adalah pemberian MP-ASI dini pada bayi usia 06 bulan. Alat pengumpul data yaitu kuesioner. Pengolahan data dilakukan dengan editing, coding, processing dan cleaning. Analisis univariate untuk melihat distribusi frekuensi dengan menggunakan rumus persentase. Analisis bivariate untuk mengetahui ada atau tidak hubungan faktor-faktor pemberian MP-ASI pada bayi usia 0-6 bulan. Uji statistik yang digunakan adalah chi-square dan menilai Odds Ratio (OR).

\section{HASIL}

Tabel 1. Distribusi Frekuensi Karakteristik Responden

\begin{tabular}{lcc}
\hline Variabel Penelitian & Frek & \% \\
\hline Pengetahuan & & \\
Baik & 67 & 72,8 \\
Kurang & 25 & 27,2 \\
\hline Pendidikan & & \\
Tinggi & 24 & 26,1 \\
Rendah & 68 & 73,9 \\
\hline Pekerjaan & & \\
Bekerja & 23 & 25,0 \\
Tidak Bekerja & 69 & 75,0 \\
\hline Pendapatan Keluarga & & \\
Tinggi & 53 & 57,6 \\
Rendah & 39 & 42,4 \\
\hline Pemberian MP-ASI Dini & & \\
Ya & 64 & 69,6 \\
Tidak & 28 & 30,4 \\
\hline Total & $\mathbf{9 2}$ & $\mathbf{1 0 0 , 0}$ \\
\hline
\end{tabular}

Pada tabel 1 menunjukkan bahwa responden berpengetahuan baik sebanyak 67 orang $(72,8 \%)$, 
berpendidikan rendah sebanyak 68 orang $(73,9 \%)$, responden yang tidak bekerja sebanyak 69 orang $(75 \%)$, serta responden dengan pendapatan keluarga tinggi sebanyak 53 orang $(57,6 \%)$ dan responden memberikan MP-ASI dini pada bayi usia $0-6$ bulan sebanyak 64 orang $(69,9 \%)$.

Tabel 2. Hubungan Pengetahuan dengan Pemberian MP-ASI Dini pada Bayi Usia 0-6 Bulan

\begin{tabular}{lcccccc}
\hline \multirow{2}{*}{$\begin{array}{c}\text { Variabel } \\
\text { Penelitian }\end{array}$} & \multicolumn{4}{c}{ Pemberian } \\
\cline { 2 - 5 } & \multicolumn{4}{c}{ Ya } & \multicolumn{4}{c}{ Tidak } & \multicolumn{2}{c}{ Total } \\
\cline { 2 - 6 } & $\mathbf{n}$ & $\mathbf{\%}$ & $\mathbf{n}$ & $\mathbf{\%}$ & $\mathbf{n}$ & $\mathbf{\%}$ \\
\hline Pengetahuan & & & & & \\
Baik & 43 & 64,2 & 24 & 35,8 & 67 & 100 \\
Kurang & 21 & 84,0 & 4 & 16,0 & 25 & 100 \\
Jumlah & 64 & 69,6 & 28 & 30,4 & 92 & 100 \\
\hline$p$ value & $0,019(\mathrm{p}<0,05)$ \\
\hline OR $(95 \% \mathrm{CI})$ & $0,229(0,062-0,844)$ \\
\hline
\end{tabular}

Pada Tabel 2 menunjukkan bahwa hasil uji statistik diperoleh nilai $p$-value $(0,019<\alpha \quad 0,05)$, artinya ada hubungan pengetahuan responden dengan pemberian MP-ASI dini pada bayi 0-6 bulan. Nilai $(\mathrm{OR}=0,229)$ artinya responden yang berpengetahuan baik mempunyai peluang 0,229 kali untuk mencegah memberikan MP-ASI dini pada bayi usia 0-6 bulan dibanding responden yang berpengetahuan kurang.

Tabel 3. Hubungan Pendidikan dengan Pemberian MP-ASI Dini pada Bayi Usia 0-6 Bulan

\begin{tabular}{|c|c|c|c|c|c|c|}
\hline \multirow{3}{*}{$\begin{array}{c}\text { Variabel } \\
\text { Penelitian }\end{array}$} & \multicolumn{4}{|c|}{$\begin{array}{c}\text { Pemberian } \\
\text { MP-ASI Dini }\end{array}$} & \multirow{2}{*}{\multicolumn{2}{|c|}{ Total }} \\
\hline & \multicolumn{2}{|c|}{ Ya } & \multicolumn{2}{|c|}{ Tidak } & & \\
\hline & $\mathrm{n}$ & $\%$ & $\mathbf{n}$ & $\%$ & $\mathbf{n}$ & $\%$ \\
\hline Pendidikan & & & & & & \\
\hline Tinggi & 21 & 87,5 & 3 & 12,5 & 24 & 100 \\
\hline Rendah & 43 & 63,2 & 25 & 36,8 & 68 & 100 \\
\hline Jumlah & 64 & 69,6 & 28 & 30,4 & 92 & 100 \\
\hline$p$ value & \multicolumn{6}{|c|}{$0,027(\mathrm{p}<0,05)$} \\
\hline OR $(95 \% \mathrm{CI})$ & \multicolumn{6}{|c|}{$0,833(0,308-2,257)$} \\
\hline
\end{tabular}

Pada tabel 3 menunjukkan bahwa hasil uji statistik diperoleh nilai $p$-value $(0,027<\alpha 0,05)$. Hal ini berarti ada hubungan antara pendidikan responden dengan pemberian MP-ASI dini pada bayi usia $0-6$ bulan. Nilai $(\mathrm{OR}=0,833)$ artinya responden yang pendidikan rendah mempunyai peluang 0,833 kali untuk mencegah memberikan MP-ASI dini pada bayi usia 0-6 bulan dibanding responden yang pendidikan tinggi.
Tabel 4. Hubungan Pekerjaan dengan Pemberian MP-ASI Dini pada Bayi Usia 0-6 Bulan

\begin{tabular}{|c|c|c|c|c|c|c|}
\hline \multirow{3}{*}{$\begin{array}{c}\text { Variabel } \\
\text { Penelitian }\end{array}$} & \multicolumn{4}{|c|}{$\begin{array}{l}\text { Pemberian } \\
\text { MP-ASI Dini }\end{array}$} & \multirow{2}{*}{\multicolumn{2}{|c|}{ Total }} \\
\hline & \multicolumn{2}{|c|}{ Ya } & \multicolumn{2}{|c|}{ Tidak } & & \\
\hline & $\mathbf{n}$ & $\%$ & $\mathbf{n}$ & $\%$ & $\mathbf{n}$ & $\%$ \\
\hline \multicolumn{7}{|l|}{ Pekerjaan } \\
\hline Bekerja & 13 & 56,5 & 10 & 43,5 & 23 & 100 \\
\hline Tidak Bekerja & 51 & 73,9 & 18 & 26,1 & 69 & 100 \\
\hline Jumlah & 64 & 69,6 & 28 & 30,4 & 92 & 100 \\
\hline$p$ value & \multicolumn{6}{|c|}{$0,295(\mathrm{p}>0,05)$} \\
\hline OR $(95 \% \mathrm{CI})$ & \multicolumn{6}{|c|}{$0,591(0,220-1,591)$} \\
\hline
\end{tabular}

Pada Tabel 4 menunjukkan bahwa hasil uji statistik diperoleh nilai $p$-value $(0,295>\alpha 0,05)$, artinya tidak ada hubungan antara pekerjaan responden dengan pemberian MP-ASI dini pada bayi usia $0-6$ bulan. Nilai $(\mathrm{OR}=0,591)$ artinya responden yang tidak bekerja mempunyai peluang 0,833 kali untuk mencegah memberikan MP-ASI dini pada bayi usia 0-6 bulan dibanding responden yang bekerja.

Tabel 5. Hubungan Pendapatan Keluarga dengan Pemberian MP-ASI Dini pada Bayi Usia 0-6 Bulan

\begin{tabular}{|c|c|c|c|c|c|c|}
\hline \multirow{3}{*}{$\begin{array}{c}\text { Variabel } \\
\text { Penelitian }\end{array}$} & \multicolumn{4}{|c|}{$\begin{array}{c}\text { Pemberian } \\
\text { MP-ASI Dini }\end{array}$} & & \\
\hline & \multicolumn{2}{|c|}{ Ya } & \multicolumn{2}{|c|}{ Tidak } & \multicolumn{2}{|c|}{ Total } \\
\hline & $\mathbf{n}$ & $\%$ & $\mathbf{n}$ & $\%$ & $\mathbf{n}$ & $\%$ \\
\hline \multicolumn{7}{|l|}{ Pendapatan } \\
\hline Tinggi & 45 & 84,9 & 8 & 15,1 & 53 & 100 \\
\hline Rendah & 19 & 48,7 & 20 & 51,3 & 39 & 100 \\
\hline Jumlah & 64 & 69,6 & 28 & 30,4 & 92 & 100 \\
\hline$p$ value & \multicolumn{6}{|c|}{$0,076(\mathrm{p}>0,05)$} \\
\hline OR $(95 \% \mathrm{CI})$ & \multicolumn{6}{|c|}{$0,426(0,164-1,107)$} \\
\hline
\end{tabular}

Pada Tabel 5 menunjukkan bahwa hasil uji statistik diperoleh nilai $p$-value $(0,0765>\alpha 0,05)$, artinya tidak ada hubungan antara pendapatan keluarga responden dengan pemberian MP-ASI dini pada bayi usia $0-6$ bulan. Nilai $(\mathrm{OR}=0,426)$ artinya responden yang pendapatan keluarga rendah mempunyai peluang 0,426 kali untuk mencegah memberikan MP-ASI dini pada bayi usia 0-6 bulan dibanding responden yang pendapatan keluarga tinggi.

\section{PEMBAHASAN}

\section{Pengetahuan}

Berdasarkan hasil penelitian yang dilakukan pada 92 responden di Wilayah Kerja Puskesmas Rumbai Pesisir Pekanbaru tentang 
determinan yang berhubungan dengan pemberian MP-ASI dini pada bayi usia 0-6 bulan diperoleh hasil yaitu terdapat hubungan yang bermakna antara pengetahuan responden dengan pemberian MP-ASI dini pada bayi usia 0-6 bulan.

Hasil penelitian ini sejalan dengan penelitian Ginting. D, Sekarwana. N, Sukandar. H (2012) tentang Pengaruh Karakteristik Faktor Internal Dan Eksternal Ibu Terhadap Pemberian Mp-Asi Dini Pada Bayi Usia <6 Bulan di Wilayah Kerja Puskesmas Barusjahe Kabupaten Karo Provinsi Sumatera Utara diperoleh nilai $p<0,001$ artinya ada hubungan pengetahuan ibu dengan pemberian MP-ASI dini pada bayi usia $<6$ bulan.

Menurut Setyaningsih (2010), bahwa pengetahuan memberikan dampak positif terhadap ibu-iu menyusui yang memberikan makanan MP-ASI tepat waktu. Sebaliknya semakin rendah pengetahuan ibu menyusui maka rendah pula pengetahuan tentang pemberian MPASI yang tepat pada bayi.

Hasil penelitian diperoleh mayoritas pengetahuan responden tentang pemberian MPASI dini adalah baik dan terdapat hubungan antara pengetahuan dengan pemberian MP-ASI dini serta mempunyai peluang lebih besar untuk mencegah pemberian MP-ASI dini kepada bayi usia $0-6$ bulan dibandingkan dengan responden yang berpengetahuan rendah. Hal ini berarti semakin baik pengetahuan seseorang maka akan semakin tahu waktu yang tepat memberikan MPASI yaitu diatas usia 6 bulan sehingga secara langsung akan memberikan ASI ekslusif kepada bayinya.

\section{Pendidikan}

Hasil penelitian yang dilakukan pada 92 responden di Wilayah Kerja Puskesmas Rumbai Pesisir Pekanbaru tentang determinan yang berhubungan dengan pemberian MP-ASI dini pada bayi usia 0-6 bulan, diperoleh hasil yaitu terdapat hubungan yang bermakna antara pendidikan responden dengan pemberian MPASI dini.

Hasil penelitian ini sejalan dengan penelitian Ibrahim, Rattu dan Pangemanan (2014) tentang Hubungan antara Karakteristik Ibu dan Perilaku Ibu dengan Riwayat Pemberian MP-ASI Dini Di Wilayah Puskesmas Atinggola Kecamatan Atinggola Kabupaten Gorontalo Utara Tahun 2014 yaitu diperoleh p-value $(0,010<\alpha 0,05)$ artinya terdapat hubungan yang bermakna antara faktor pendidikan dengan pemberian MP-ASI dini. Ibu yang berpendidikan rendah akan lebih mudah menerima pesan atau informasi yang disampaikan orang lain karena berdasarkan pengalaman dan budaya yang ada pada masyarakat setempat. Dari hasil wawancara diperoleh keterangan bahwa masalah budaya atau tradisi yang ada pada masyarakat yang sudah berlangsung secara turun temurun, dimana bayi yang baru lahir masih akan menjalani ritual harus diazankan untuk anak laki-laki dan diqamatkan untuk anak perempuan, kemudian sebagai minuman atau makanan pembuka diistilahkan "buka puasa" diberikan madu atau air gula. Alasan lain karena pada saat setelah lahir ASI belum keluar atau sedikit, sehingga bisa menyebabkan bayi menangis dan susah tidur.

Hasil penelitian yang telah dilakukan diperoleh mayoritas responden berpendidikan rendah, secara statistik terdapat hubungan antara faktor pendidikan dengan pemberian MP-ASI dini dan mempunyai peluang lebih besar untuk mencegah pemberian MP-ASI dini kepada bayi usia 0-6 bulan dibandingkan dengan responden yang berpendidikan tinggi. Menurut asumsi peneliti, bahwa prilaku pemberian MP-ASI dini dipengaruhi oleh multifaktor seperti budaya/ tradisi, pengalaman, lingkungan dan sumber informasi. Seseorang yang berpendidikan rendah tidak selalu cenderung memberikan MP-ASI dini.

\section{Pekerjaan}

Hasil penelitian yang dilakukan pada 92 responden di Wilayah Kerja Puskesmas Rumbai Pesisir Pekanbaru tentang determinan yang berhubungan dengan pemberian MP-ASI dini pada bayi usia $0-6$ bulan diperoleh hasil yaitu tidak terdapat hubungan yang bermakna antara pekerjaan responden dengan pemberian MP-ASI dini.Hasil penelitian ini sejalan dengan penelitian yang dilakukan oleh Padang (2008) tentang Analisis Faktor-Faktor Yang Mempengaruhi Ibu Dalam Pemberian MP-ASI Dini Di Kecamatan Pandan Kabupaten Tapanuli Tengah Tahun 2007 diperoleh nilai $p$-value $=0,205>0,05$ yang berarti tidak terdapat hubungan yang signifikan antara pekerjaan dengan kejadian pemberian MP-ASI dini.

Hasil Penelitian yang dilakukan Kristianto \& Sulistyarini (2013) tentang Faktor yang Mempengaruhi Perilaku Ibu Dalam Pemberian MP-ASI pada Bayi Umur 6-36 Bulan diperoleh hasil $p$-value $=0,992>0,05$ arinya faktor pekerjaan tidak ada hubungan dengan pemberian MP-ASI terlalu dini. Pekerjaan ibu rumah tangga atau tidak bekerja cenderung memberikan MP-ASI dini karena memiliki keyakinan yang dilatarbelakangi oleh aspek budaya bahwa bayi akan rewel jika hanya diberikan ASI ekslusif selama 6 bulan, sehingga ibu memutuskan untuk 
memberikan MP-ASI kurang dari 6 bulan. Hal yang sama juga dikemukakan oleh Wawan (dalam Oktova, 2016) bahwa lingkungan adalah segala sesuatu yang ada disekitar individu baik lingkungan fisik, biologis maupun sosial. Lingkungan berpengaruh terhadap proses masuknya pengatahuan ke dalam individu yang berbeda dalam lingkungan tersebut. Hal ini terjadi karena adanya interaksi timbal balik ataupun yang direspon sebagai pengetahuan oleh setiap individu.

Hasil penelitian yang telah dilakukan diperoleh bahwa mayoritas pekerjaan responden adalah tidak bekerja, secara statistik tidak terdapat hubungan pekerjaan dengan pemberian MP-ASI dini dan mempunyai peluang lebih besar untuk mencegah pemberian MP-ASI dini pada bayi usia 0-6 bulan dibandingkan dengan responden yang bekerja. Menurut asumsi peneliti, status pekerjaan tidak selalu mempengaruhi prilaku pemberian MP-ASI dini pada bayinya dimana, ibu yang bekerja tidak selalu cenderung memberikan MP-ASI dini begitu juga ibu yang tidak bekerja tidak selalu cenderung memberikan MP-ASI dini. Hal ini dipengaruhi oleh multifaktorial yang mempengaruhi pemberian MP-ASI dini pada bayi usia 0-6 bulan seperti budaya atau tradisi, norma-norma, pengalaman, pengetahuan, pendidikan, lingkungan serta sumber informasi.

\section{Pendapatan Keluarga}

Berdasarkan hasil penelitian yang dilakukan pada 92 responden di Wilayah Kerja Puskesmas Rumbai Pesisir Pekanbaru tentang determinan yang berhubungan dengan pemberian MP-ASI dini pada bayi usia 0-6 bulan diperoleh hasil tidak terdapat hubungan yang bermakna antara pendapatan keluarga responden dengan pemberian MP-ASI dini.

Menurut hasil penelitian Muliawati \& Irkanik (2014) tentang Faktor-faktor yang Melatarbelakangi Pemberian Makanan Pendamping ASI pada Bayi 0-6 Bulan di Posyandu Flamboyan Kelurahan Kerten Kecamatan Laweyan Surakartadiperoleh pendapatan keluarga mempengaruhi ibu memberikan makanan pendamping ASI terlalu dini yaitu dilihat dari daya beli terhadap makanan pendamping ASI yaitu jika semakin baik pendapatan keluarga maka daya beli akan makanan tambahan juga mudah, sebaliknya semakin buruk perekonomian keluarga, maka daya beli akan makanan tambahan lebih sukar. Hasil penelitian yang sama juga dilakukan oleh Afriyani, Khalisa \& Rolina (2016) bahwa pendapatan yang tinggi cenderung memiliki aktivitas yang terbatas di rumah sehingga bagi mereka yang memiliki bayi untuk mengatasi hal tersebut biasanya mereka akan mengerjakan seorang pengasuh untuk merawatnya serta mengganti ASI eksklusif dengan susu formula. Selain itu, keluarga yang pendapatannya tinggi cenderung lebih mampu membeli susu formula dibandingkan dengan keluarga yang pendapatannya rendah. Bagi mereka yang pendapatannya rendah akan memiliki pemikiran yang berbeda, mereka menganggap pendapatan lebih baik dipergunakan untuk membeli kebutuhan sehari-hari dari pada membeli susu formula.

Hasil penelitian diperoleh mayoritas pendapatan keluarga responden adalah kategori tinggi, secara statistik tidak terdapat hubungan antara faktor pendapatan keluarga dengan pemberian MP-ASI dini dan pendapatan keluarga kategori rendah mempunyai peluang lebih besar untuk mencegah pemberian MP-ASI dini pada bayi usia 0-6 bulan dibandingkan dengan responden pendapatan keluarga tinggi. Menurut asumsi peneliti, bahwa banyak faktor yang mempengaruhi pemberian MP-ASI dini pada bayi usia 0-6 bulan seperti budaya, tradisi, pengalaman, lingkungan dan sebagainya. Pendapatan keluarga yang tinggi tidak selalu cenderung memberikan MP-ASI dini pada bayinya begitu juga pendapatan keluarga yang rendah.

\section{SIMPULAN}

1. Distribusi frekuensi ibu yang mempunyai bayi 0-6 bulan di Wilayah Kerja Puskesmas Rumbai Pesisir Pekanbaru periode JanuariDesember 2015 mayoritas memiliki pengetahuan baik, mayoritas memiliki tingkat pendidikan rendah, mayoritas tidak bekerja dan pendapatan keluarga tinggi.

2. Terdapat hubungan antara pengetahuan, pendidikan dan pekerjaan dengan pemberian MP-ASI dini pada bayi usia 0-6 bulan

3. Tidak terdapat hubungan antara pendapatan keluarga dengan pemberian MP-ASI dini pada bayi usia $0-6$ bulan

\section{SARAN}

1. Bagi pihak Puskesmas Rumbai Pesisir Pekanbaru diharapkan hasil penelitian ini dapat dijadikan salah satu pertimbangan dan informasi yang dipergunakan untuk meningkatkan pengetahuan masyarakat 
dengan cara mensosialisasikan dan bekerjsama dengan kader kesehataan dan tokoh masyarakat tentang pemberian MPASI berupa penyuluhan bimbingan yang terarah kepada ibu-ibu yang mempunyai bayi usia $0-6$ bulan sehingga meningkatkan

\section{DAFTAR PUSTAKA}

Arif, N. 2009. Panduan Ibu Cerdas ASI Dan Tumbuh Kembang Bayi. Yogyakarta: Media Pressindo.

Afriyani, R., Halisa, S., \& Rolina, H. 2016. Faktor-Faktor yang Berhubungan dengan Pemberian MP-ASI pada Bayi Usia 0-6 Bulan di BPM Nurtila Palembang. Jurnal Kesehatan. $\quad$ http://www.poltekkestjk.ac.id/index.php/JK (Diakses pada 22 Januari 2017).

BPS. 2015. Badan Pusat Statistik. http://www.bps.go.id/Subjek/view/id/6 (Diakses pada 09 November 2016).

Budiman \& Agus, R. 2014. Kapita Selekta Kuesioner Pengetahuan dan Sikap dalam Penelitian Kesehatan. Jakarta: Salemba Medika.

Dinkes Provinsi Riau. 2014. Profil Kesehatan Provinsi Riau 2014: Cakupan Pemberian ASI Ekslusif. http://dinkesriau.net (Diakses 14 Januari 2017)

Depkes. 2006. Pedoman Umum Pemberian Makanan Pendamping ASI (MP-ASI) Lokal. http://gizi.depkes.go.id (Diakses pada 29 Januari 2017).

Fadhila, S, R \& Ninditya, L. 2016. IDAI: Dampak Dari Tidak Menyusui Di Indonesia. http://www.idai.or.id(Diakses pada 03 Januari 2017).

Ginting. D, Sekarwana. N, Sukandar. H. 2012. Pengaruh Karakteristik, Faktor Internal dan Eksternal Ibu Terhadap Pemberian MP-ASI Dini Pada Bayi <6 Bulan Di Wilayah Kerja Puskesmas Barusjahe Kabupaten Karo Provinsi Sumatera Utara. http://repository.unpad.ac.id/15304/

(Diakses 10 April 2017)

Imelda, R. 2010. Panduan Kehamilan \& Perawatan Bayi dari A-Z. Surabaya: Victory.

Ibrahim, Rattu dan Pangemanan. 2014. Hubungan antara Karakteristik Ibu dan Perilaku Ibu dengan Riwayat Pemberian MP-ASI Dini di Wilayah Puskesmas Atinggola Kecamatan Atinggola Kabupaten Gorontalo Utara. Jurnal pengetahuan dan kesadaran tentang Makanan Pendamping ASI (MP-ASI).

2. Bagi peneliti selanjutnya agar dapat meneliti tentang variabel lain yang berhubungan dengan pemberian MP-ASI dini pada bayi usia $0-6$ bulan seperti sosial budaya, kebiasaan dan prilaku.

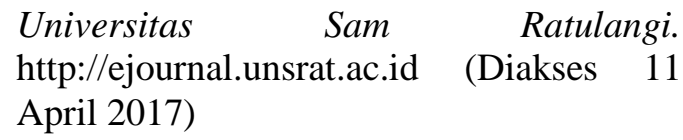

Kemenkes RI. 2016. Profil Kesehatan Indonesia 2015: Pemberian ASI Ekslusif. http://www.depkes.go.id (Diakses 12 Januari 2017)

Kemenkes RI. 2013. Riset Kesehatan Dasar 2013: Kesehatan Anak. http://www.depkes.go.id (Diakses 14 Januari 2017)

Kristianto, Y \& Sulistyarini, T. 2013. Faktor Yang Mempengaruhi Perilaku Ibu Dalam Pemberian Makanan Pendamping ASI Pada Bayi Umur 6-36 Bulan. Stikes RS Bapita Kediri. http://puslit2.petra.ac.id (Diakses pada 07 Januari 2017).

M.DHS. 2013.Survey Demografi Kesehatan Indonesia 2012: Perbedaan Demografis pada Kematian Bayi dan Anak. http://chnrl.org/pelatihan-demografi (Diakses 12 Januari 2017).

Muliawati \& Irkanik.2014.Faktor-faktor yang Melatarbelakangi Pemberian Makanan Pendamping ASI pada Bayi 0-6 Bulan di Posyandu Flamboyan Kelurahan Kerten Kecamatan Laweyan Surakarta.Jurnal Akademi Kebidanan Citra Medika Surakarta. http://ejurnal.akbidem.ac.id (Diakses pada 24 Januari 2017).

Oktova, R. 2016. Hubungan Pengetahuan dan Sikap Remaja Putri tentang Rebusan Daun Sirih dalam Mengatasi Keputihan di SMAN 11 Pekanbaru. Jurnal Kesehatan. http://www.poltekkes-

tjk.ac.id/index.php/JK (Diakses pada 5 Januari 2017).

Padang, A. 2008. Analisa Faktor-Faktor yang Mempengaruhi Ibu dalam Pemberian MPASI Dini di Kecamatan Pandan Kabupaten Tapanuli Tengah Tahun 2008. http://repository.usu.ac.id (Diakses pada 23 Januari 2017).

Setyaningsih., A. 2010. Hubungan Karakteristik Ibu Dengan Pemberian MP-ASI Dini pada Bayi Usia 0-6 Bulan di Posyandu Warna 
Sari Desa Glonggong Nogosari Boyolali. Jurnal Kebidanan STIKES Estu Utomo Boyolali. http://journal.stikeseub.ac.id (Diakses 10 April 2017).
Suparyanto. 2014. Konsep Dasar Pendapatan Keluarga. http://dr-suparyanto (Diakses pada 27 Januari 2017).

Wawan \& Dewi. 2011. Teori \& Pengukuran Pengetahuan, Sikap, dan Perilaku Manusia. Yogyakarta: Nuha Medika. 